\title{
Foraging time strategy of small juvenile plaice: a laboratory study of diel and tidal behaviour patterns with Artemia prey and shrimp predators
}

\author{
M. T. Burrows \\ Dunstafinage Marine Laboratory, PO Box 3, Oban, Argyll PA34 4AD, Scotland, UK
}

\begin{abstract}
The natural pattern over time of foraging and migration in juvenile plaice Pleuronectes platessa has evolved to enhance the survival of the fish. It is a product of endogenous rhythms and direct responses to biological and physical conditions, including their predators and prey. This study aimed to determine the relative roles of these influences through experimental manipulation of the physical and biological conditions. Infrared television cameras and illumination were used to observe freshly caught juvenile plaice in the light and dark over $24 \mathrm{~h}$ periods in arena tanks. Single Crangon crangon and Artemia nauplij were added to these tanks as predators and food respectively. The behaviour of juvenile plaice in the light was dominated by swimming on the sand surface, with little activity on the bottom during darkness. Most swimming on the bottom occurred 0 to $2 \mathrm{~h}$ after the expected time of high water. Activity in darkness largely comprised swimming in the water column or at the surface, with most swimming seen 2 to $4 \mathrm{~h}$ after high water. Off-bottom swimming was also seen at this time in the light. Artemia as prey reduced swimming on the bottom during the light period, but had no effect on off-bottom activity. The presence of single $C$. crangon in the tank had no discernible effect on behaviour. Different functions are proposed for pelagic and benthic swimming. Both may be used for migration while pelagic swimming may avoid predators on the bottom at night. Benthic swimming may be used for foraging.
\end{abstract}

KEY WORDS: Pleuronectes platessa - Endogenous rhythms · Feeding · Predation risk · Crangon crangon

\section{INTRODUCTION}

Juvenile plaice Pleuronectes platessa live in an environment dominated by tidal changes in habitat availability (Kuipers 1973). Changes in light levels between day and night strongly influence their ability, using vision, to detect and be detected by their predators (Ansell \& Gibson 1993) and to detect and capture their prey (Blaxter 1968); juvenile plaice mostly feed in daylight (Edwards \& Steele 1968, Thijssen et al. 1974, Lockwood 1980). Soon after settlement juvenile plaice develop patterns of migration (van der Veer \& Bergman 1986), partly driven by endogenous rhythms (Gibson 1973a, 1975), which allow them to exploit their complex and variable habitat to best advantage (Burrows 1994).

The migration of juvenile plaice into the intertidal zone with rising tides is well documented (Edwards \& Steele 1968, Berghahn 1983, Ansell \& Gibson 1990) and apparently ubiquitous, occurring over a range of habitats from sandy beaches on exposed coasts (Gibson 1973a) to sheltered intertidal sandflats (Kuipers 1973). There may also be a diurnal positional change. In some habitats plaice move into shallower water in the dark hours (Burrows et al. 1994a), while in others the extent of tidal migration is reduced in the dark (Berghahn 1986). Since migration is energetically costly, there are likely to be strong selective pressures for this activity. Among those factors suggested are: maintenance of position in a moving physiologically optimal zone (Rountree \& Able 1992), avoidance of competition and replenishment of food resources, avoidance of predators (Ansell \& Gibson 1990), the benefits of finding temporarily available food (Wolff et al. 1981, Berghahn 1987), or a combination of the last two (Burrows 1994).

Migration patterns of juvenile plaice have a direct parallel in the vertical migrations of pelagic fishes and zooplankton (e.g. Forward 1988, Frost \& Bollens 1992). Current explanations of these migrations are based on 
their utility as feeding and predator-avoidance strategies (Clark \& Levy 1988) and in selective current transport (Hill 1991, Metcalfe et al. 1991).

When removed from their natural habitat and maintained in constant laboratory conditions, juvenile plaice continue to show cycles of activity similar to those seen in the field (Gibson 1973b, 1975), albeit without, as yet, a detectable directional component. The endogenous rhythm which produces these changes is at the centre of the mechanism which produces the appropriate patterns of feeding, migration and other behaviour

The aim of this study is to elucidate the function of observed patterns of movement and behaviour in natural conditions (Gibson 1980, Burrows et al, 1994a). Since juvenile plaice normally range over many hundreds of metres in their natural habitat, observations are not possible on individuals over long periods in nature, nor can their environment be directly manipulated. In this study, therefore, long-term behaviour was observed in experimental sand-bottomed tanks ('arenas') in the laboratory. The possible effects of food availability and the presence of predators on behaviour were examined by addition of these items to the experimental arenas to determine their effects on the expression of endogenously controlled behaviour in freshly caught fish. Newly hatched Artemia nauplii were used as food, since this is an organism on which the juvenile plaice (<30 $\mathrm{mm}$ in length) used here readily feed (Riley 1966, Wyatt 1972), while single brown shrimps Crangon crangon, the major cause of mortality in juvenile plaice of this size in the Wadden Sea (van der Veer \& Bergman 1987), were used as predators.

\section{MATERIALS AND METHODS}

Materials. Juvenile plaice and the brown shrimp Crangon crangon (hereafter 'Crangon') were collected from Dunstaffnage Bay, a sheltered area of muddy sand facing northeast, some $5 \mathrm{~km}$ north of Oban on the west coast of Scotland ( $\left.56^{\circ} 30^{\prime} \mathrm{N}, 5^{\circ} 20^{\prime} \mathrm{W}\right)$. On $20 \mathrm{day}$ time low tides between 26 April and 20 May 1993, 2 plaice were caught using a hand-pulled $0.5 \mathrm{~m}$ net in 0.5 to $1.0 \mathrm{~m}$ of water These plaice ranged in size from 14 to $35 \mathrm{~mm}$ in total length, with a mean total length of $24 \mathrm{~mm}$. On alternate sampling occasions, 2 large Crangon were also selected from those caught in the net to serve as predators in the experimental arenas. They were from 38 to $54 \mathrm{~mm}$ in total length, with a mean of $45 \mathrm{~mm}$

Newly hatched Artemia nauplii (AF grade from Artemia Systems NV, Baasrode, Belgium) were used as prey for the juvenile plaice.
Experimental arenas. Two glass aquarium tanks $(60$ $\times 29 \times 37 \mathrm{~cm}$ ) were used for experimental arenas. There were filled to a depth of $2 \mathrm{~cm}$ with coarsely sieved (2 $\mathrm{mm}$ mesh) and washed wind-blown sand from a local sandy beach and a water depth of $30 \mathrm{~cm}$. The tanks were illuminated from above during the light period with 4 overhead $65 \mathrm{~W}$ fluorescent tubes and continuously from one side with single $300 \mathrm{~W}$ underwater lamps in a cooling bath with flowing water. Infrared filters with $740 \mathrm{~nm}$ minimum transmission wavelength cutting out light visible to the fish (Blaxter 1969) were fitted to the underwater lamps to provide illumination for video recording in the light and dark periods.

The behaviour of the juvenile plaice in each arena was monitored using a black and white video camera also fitted with an infrared filter, positioned to give a full lateral view of the inside of the aquarium tank from its end. These video images were recorded on timelapse video tape with recorders (Panasonic AG 6024) set at 3.6 frames $\mathrm{s}^{-1}$. The view of each tank was sufficient to allow the plaice and Crangon to be observed at all times.

The water temperature in the tanks was controlled by placing them in an air-conditioned room with an air temperature of $8^{\circ} \mathrm{C}$. Temperatures in the tanks were between 10.4 and $12.6^{\circ} \mathrm{C}$, with a mean of $11.7^{\circ} \mathrm{C}$, and were thus raised slightly by the heating effect of the infrared illumination.

Experimental protocol. The Artemia nauplii were added in excess to one of the arena tanks (with food treatment, $+F$ ). These were replaced every other day by complete siphoning and refilling of the tanks. Single juvenile plaice were added to the arenas within $30 \mathrm{~min}$ of collection and their behaviour was videotaped for the next $24 \mathrm{~h}$. On alternate days a single Crangon was also added to each tank to serve as a predator (with predator treatment, $+\mathrm{P}$ ). At the end of each experimental period the fish and Crangon were removed, killed with an overdose of anaesthetic (Benzocaine) and preserved in $4 \%$ formalin in sea water Soon after preservation the juvenile plaice were measured and their stomachs removed and dissected. The number of Artemia nauplii in the stomachs of those from the with food $(+F)$ treatment was counted as a measure of feeding success

The arenas were lit in the visible spectrum over a fixed $16 \mathrm{~h}: 8 \mathrm{~h}$ light:dark cycle, with lights on between 04:00 and 20:00 h, approximating the natural cycle at the time of the experiment.

Analysis of video recordings. The behaviour of the juvenile plaice was scored during the first $10 \mathrm{~min}$ of each hour. Six different elements of behaviour were recognised, similar to those observed in natural conditions (Gibson 1980): (1) Swim, a movement on or close 
to the bottom; (2) Rise, a completely pelagic swimming movement; (3) Crawl, when the plaice settled and moved on the glass sides of the tank; (4) Bury; (5) Encounter with the Crangon predator; and (6) Bite. The time and duration of these elements were logged with a PC-based keyboard event recorder which registered the video timecode from a video timecode reader (IMP Electronics V90020A).

The Crangon was assigned as active if it moved during the 10 min observation period.

\section{RESULTS}

\section{Frequency of types of behaviour}

The most frequent element of behaviour was shortduration swimming near the bottom (Swim 84.6\%). Off-bottom activity, either pelagic swimming (Rise $9.5 \%$ ) or crawling on the sides of the aquarium tank (Crawl $5.7 \%$ ), formed the majority of the remaining events. Burying, predator encounters and observed bites were very rare $(0.2 \%)$.

The juvenile plaice were in motion for 2 to $5 \%$ of the total time observed in each hour in the light, with the remaining 95 to $98 \%$ spent motionless on the bottom. In the dark, the plaice were typically active for 10 to $35 \%$ of the time, especially in the $4 \mathrm{~h}$ after the expected time of high water.

\section{Temporal patterns of behaviour in juvenile plaice}

The frequencies of the 3 most common elements of behaviour (Swim, Rise, Crawl) per 10 min observation period were subjected to analysis of variance (ANOVA) to look for significant differences among times of day, states of the tide and in the presence and absence of a Crangon predator and Artemia prey. Frequencies $(f)$ were transformed to $\log _{10}(1+f)$ before analysis. The effects of the presence of a Crangon predator and Artemia prey were tested by comparing mean frequencies for individual fish within these treatments (see Table 1, Fig. 1). The remaining effects, time, light conditions and the interdependence of treatment effects with time and light, were tested using the hourly frequencies of events in individual trials.

Two ANOVA designs were used. In the first the frequency of behavioural elements was analysed with respect to the time relative to the first high water after capture and whether light or dark. In the second, the frequency of behavioural elements was analysed relative to the time of day.

Benthic swimming movements showed a tidal cycle of occurrence (Fig. 1a; Table 1a: HW1HR effect). In
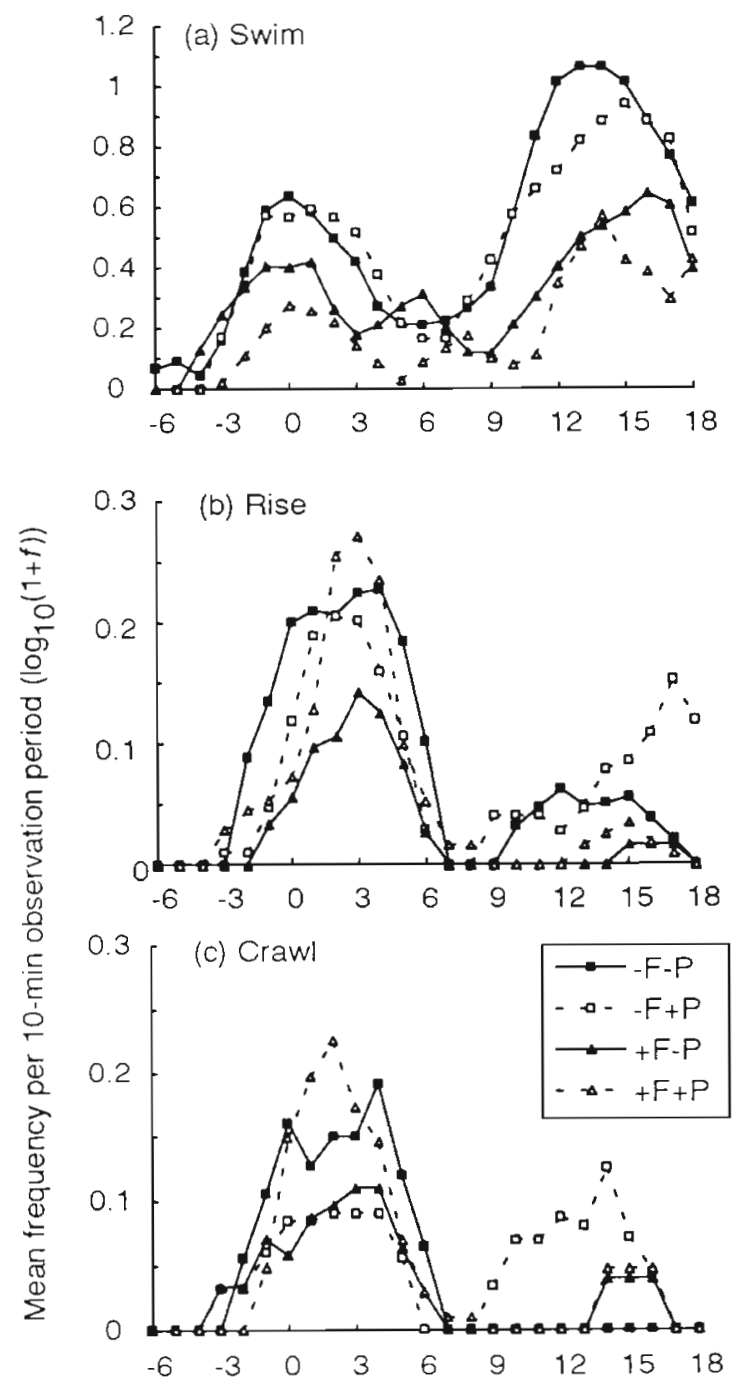

(d) Average number of replicates

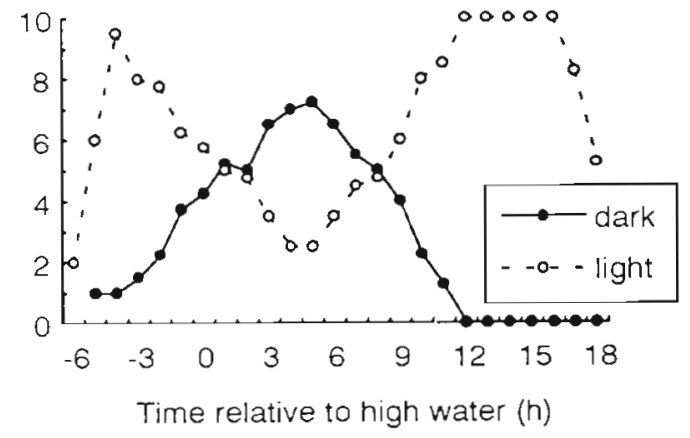

Fig. 1. Pleuronectes platessa. Temporal patterns of occurrence of (a) benthic swimming, (b) pelagic swimming, and (c) crawling on the sides of the tank, relative to the expected time of the first high water after capture (0). Each line is a $3 \mathrm{~h} \mathrm{mov-}$ ing average of the frequency $\left[\left(\log _{10}(1+f)\right.\right.$ transformed] of events per 10 min observation period per hour, averaged over 10 trials per treatment $(-\mathrm{F}-\mathrm{P},-\mathrm{F}+\mathrm{P},+\mathrm{F}-\mathrm{P},+\mathrm{F}+\mathrm{P})$. The lowest plot (d) shows the average number of replicate observations per treatment for each hour occurring in the light $104: 00 \mathrm{~h}$ to 20:00 h) and in the dark (20:00 to 04:00 h) 
Table 1 pleuronectes platessa. Summary of analyses of variance of $\log _{10}(1+f)$ transformed frequencies of benthic swimming (Swim), pelagic swimming (Rise), and crawling on the sides of the tanks (Crawl). In the top half of the table (a) frequencies were analysed with respect to the hour relative to the time of the first high water (HW1HR: -2 to +11 ), light conditions (LIGHT: light, dark), and the presence of Artemia food (FOOD: with, without) and a Crangon predator (PRED: with, without). Main effects of food and a predator were tested over variation between individual fish, while other effects were tested over the residual variation. In the bottom half of the table (b) frequencies were analysed relative to the hour of the day (DHOUR: 0 to 23)

\begin{tabular}{|c|c|c|c|c|c|c|c|}
\hline Source & $\mathrm{df}$ & $\begin{array}{l}\text { Swim } \\
p>F\end{array}$ & & $\begin{array}{l}\text { Rise } \\
p>F\end{array}$ & & $\begin{array}{l}\text { Crawl } \\
p>F\end{array}$ & \\
\hline \multicolumn{8}{|c|}{ (a) Light conditions and time relative to high water } \\
\hline PRED & 1 & 0.5560 & ns & 0.9052 & ns & 0.9125 & ns \\
\hline FOOD & 1 & 0.0297 & $\cdot$ & 0.3505 & ns & 0.6998 & ns \\
\hline PRED $\times$ FOOD & 1 & 0.4015 & ns & 0.4324 & ns & 0.4729 & ns \\
\hline Fish in trials within treatments & 36 & 0.0001 & $\cdots$ & 0.0001 & $\cdots$ & 0.0001 & $\cdots$ \\
\hline HW1HR & 12 & 0.0565 & ns & 0.0026 & $\because$ & 0.0088 & $\cdot \cdot$ \\
\hline PRED $\times$ HW $1 H R$ & 12 & 0.4326 & ns & 0.8224 & ns & 0.8145 & ns \\
\hline FOOD $\times$ HW $1 \mathrm{HR}$ & 12 & 0.7164 & ns & 0.8261 & ns & 0.9927 & ns \\
\hline$P R E D \times F O O D \times H W 1 H R$ & 12 & 0.8839 & ns & 0.9391 & ns & 0.8808 & ns \\
\hline LIGHT & 1 & 0.0001 & $\cdots$ & 0.0013 & $\cdot \cdot$ & 0.0110 & $\cdot$ \\
\hline PRED $\times$ LIGHT & 1 & 0.1717 & ns & 0.3047 & ns & 0.0973 & ns \\
\hline FOOD $\times$ LIGHT & 1 & 0.0001 & $\cdots$ & 0.3978 & ns & 0.3538 & ns \\
\hline PRED $\times$ FOOD $\times$ LIGHT & 1 & 0.8280 & ns & 0.5090 & ns & 0.5173 & ns \\
\hline $\mathrm{HW} 1 \mathrm{HR} \times \mathrm{LIGHT}$ & 12 & 0.7553 & ns & 0.1431 & ns & 0.6430 & ns \\
\hline $\mathrm{FOOD} \times \mathrm{HW} 1 \mathrm{HR} \times \mathrm{LIGHT}$ & 12 & 0.8940 & ns & 0.6108 & ns & 0.8963 & ns \\
\hline PRED $\times$ HW $1 \mathrm{HR} \times \mathrm{LIGHT}$ & 12 & 0.5592 & ns & 0.6090 & ns & 0.7291 & ns \\
\hline \multicolumn{8}{|l|}{ (b) Time of day } \\
\hline PRED & 1 & 0.3684 & ns & 0.5857 & ns & 0.6497 & ns \\
\hline FOOD & 1 & 0.0082 & $\because$ & 0.1717 & ns & 0.6858 & ns \\
\hline $\mathrm{PRED} \times \mathrm{FOOD}$ & 1 & 0.6310 & ns & 0.6434 & ns & 0.8875 & ns \\
\hline Fish in trials within treatments & 36 & 0.0001 & $\cdots$ & 0.0001 & $\cdots$ & 0.0001 & $\cdots$ \\
\hline DHOUR & 23 & 0.0001 & $\cdots$ & 0.0001 & $\cdots$ & 0.0001 & $\cdots$ \\
\hline PRED $\times$ DHOUR & 23 & 0.8531 & ns & 0.7175 & nos & 0.6850 & ns \\
\hline FOOD $\times$ DHOUR & 23 & 0.0078 & $\cdots$ & 0.7931 & ns & 0.3338 & ns \\
\hline$P R E D \times F O O D \times D H O U R$ & 23 & 0.9596 & ns & 0.6445 & ns & 0.7731 & ns \\
\hline
\end{tabular}

Table 2. Crangon crangon. Analyses of variance of activify per 10 min observation period per hour: (a) relative to light conditions (LIGHT: light, dark), the time relative to high water (HW1HR: -6 to +18), and the presence of food (FOOD: with, without); and (b) relative to the hour of the day (DHOUR: 0 to 23). The overall effect of the presence of food was tested over the variation in activity between individual Crangon within each treatment. Significance indicated as in Table 1

\begin{tabular}{|c|c|c|c|c|c|c|}
\hline Source & df & Type III SS & MS & F-value & $p>F$ & \\
\hline \multicolumn{7}{|c|}{ (a) Light conditions and time relative to high water } \\
\hline FOOD & 1 & 0.434 & 0.434 & 1.24 & 0.2798 & ns \\
\hline Crangon in trials within treatments & 18 & 6.297 & 0.350 & 2.64 & 0.0003 & $\cdots$ \\
\hline HW1HR & 25 & 12.554 & 0.502 & 3.79 & 0.0001 & $\cdots$ \\
\hline FOOD $\times$ HW $1 \mathrm{HR}$ & 25 & 2.529 & 0.101 & 0.76 & 0.7884 & ns \\
\hline LIGHT & 1 & 5.937 & 5.937 & 44.82 & 0.0001 & $\cdots$ \\
\hline FOOD $\times$ LIGHT & 1. & 0.168 & 0.168 & 1.27 & 0.2602 & ns \\
\hline Error & 394 & 52.197 & 0.132 & & & \\
\hline \multicolumn{7}{|l|}{ (b) Time of day } \\
\hline FOOD & 1 & 0.392 & 0.392 & 1.08 & 0.3120 & ns \\
\hline Crangon in trials within treatments & 18 & 6.522 & 0.362 & 2.36 & 0.0015 & $\cdots$ \\
\hline DHOUR & 23 & 16.575 & 0.721 & 4.69 & 0.0001 & $\cdots$ \\
\hline FOOD $\times$ DHOUR & 23 & 3.713 & 0161 & 1.05 & 0.4008 & ns \\
\hline Error & 400 & 61.506 & 0.154 & & & \\
\hline
\end{tabular}


each treatment a first maximum frequency occurred at or $1 \mathrm{~h}$ after the expected time of the first high water after capture. A second larger peak was seen around 14 to $16 \mathrm{~h}$ after the first high water. The second peak was larger, being entirely in the light (Fig. 1d) since most benthic swimming was seen in the light with very little in the dark (Table 1a: LIGHT effect; Fig 2a). The
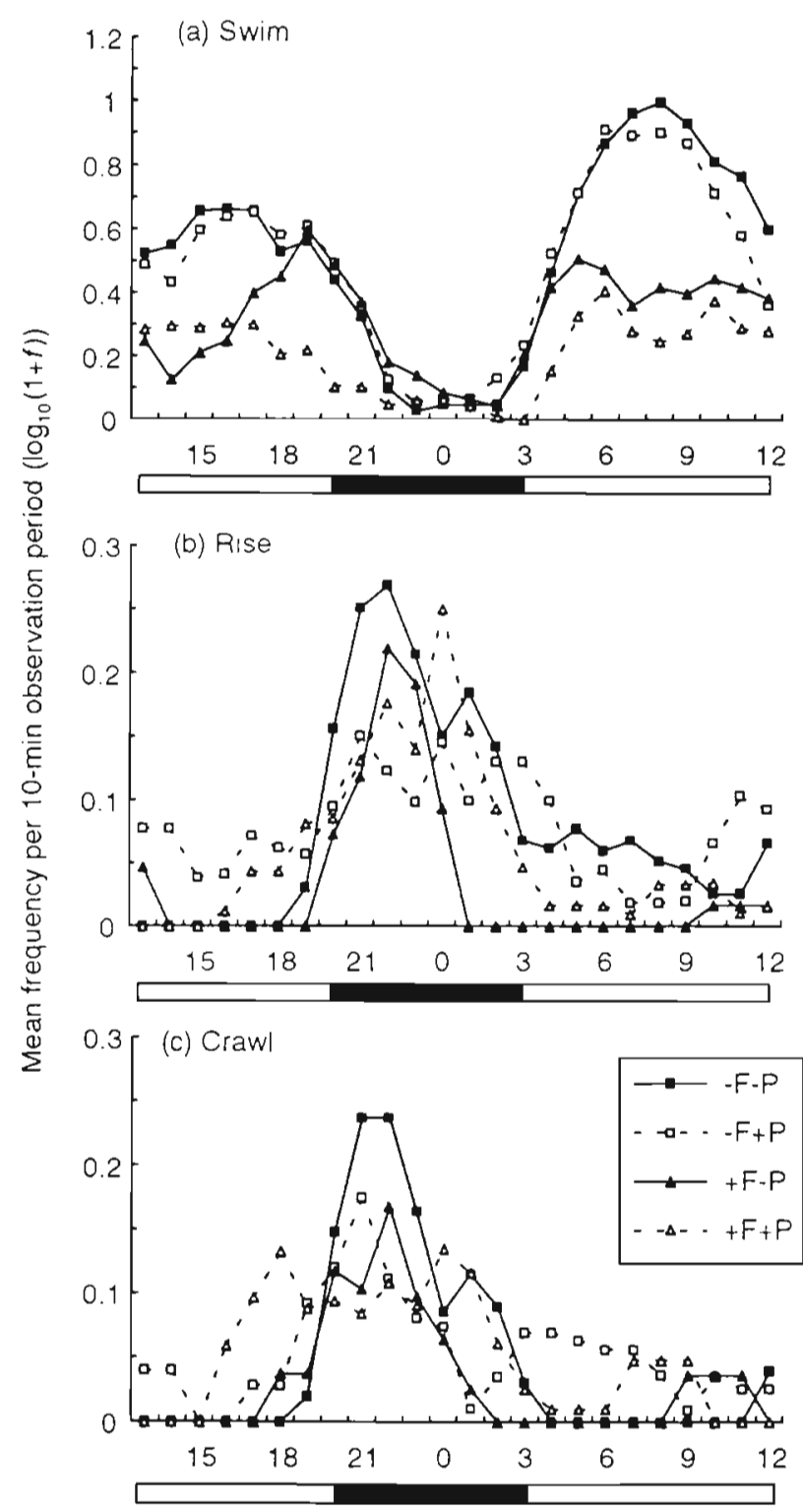

Time of day

Fig. 2. Pleuronectes platessa. Temporal patterns of occurrence of (a) benthic swimming, (b) pelagic swimming, and (c) crawling on the sides of the tank, relative to the time of day. Each line is a $3 \mathrm{~h}$ moving average of the frequency $\left[\log _{10}(1+f)\right.$ transformed] of events per $10 \mathrm{~min}$ observation period per hour, averaged over 10 trials per treatment $(-\mathrm{F}-\mathrm{P}$, $-F+P,+F-P,+F+P)$. The bar beneath each plot shows the dark and light periods fish showed more benthic swimming in the absence of food but not at the expected time of low water $(+6 \mathrm{~h}$; Table 1a: FOOD $\times$ HW1HR effect). While the presence of food reduced benthic swimming in the light, it had little effect on the much less frequent benthic activity in the dark (FOOD $\times$ LIGHT effect) The effects of light on benthic movements were most strongly evident in the patterns relative to time of day (Fig. $2 \mathrm{a}$; Table $1 \mathrm{~b}$ : DHOUR). The effects of the presence of food were most evident at the beginning of the light period (Fig. 2a: 05:00 to 12:00 h; Table 1b: FOOD $\times$ DHOUR effect).

Pelagic swimming and crawling on the sides of the tank showed very similar patterns of occurrence among treatments, times of day and states of the tide (compare Fig. $1 \mathrm{~b}$ with $1 \mathrm{c}$, and Fig. $2 \mathrm{~b}$ with $2 \mathrm{c}$ ). Offbottom activity was also strongly related to the tidal cycle. Crawls and Rises reached peak frequencies 2 to $4 \mathrm{~h}$ after the expected time of the first high water, and some $12 \mathrm{~h}$ later, 14 to $17 \mathrm{~h}$ after the first high water (Fig. 1b, c; Table 1a: Rise and Crawl HW1HR effect). Both these kinds of behaviour were much more evident in the dark (Table 1a: LIGHT effect; Table 1b: DHOUR effect). The presence of food did not affect the amount of off-bottom activity (Table 1: Rise and Crawl, all FOOD effects not significant, $p>0.05$ ), nor did the presence of the Crangon predator affect pelagic swimming. Juvenile plaice did, however, spend more time crawling on the tank walls in the light in the presence of the Crangon (Fig. 1c; Table 1a: PRED $\times$ LIGHT effect).

\section{Temporal patterns of activity in Crangon}

The individual Crangon were most active 2 to $3 \mathrm{~h}$ after the expected time of the first high water in both light and dark and both with and without live Artemia as food. A second smaller activity peak was also seen in the light $12 \mathrm{~h}$ later (Fig. 3a). Activity levels were much greater in the dark (Tables 2a, b: LIGHT, DHOUR effects; Fig. 3a, b) but were not significantly altered by the presence of food.

\section{Feeding success in juvenile plaice}

Stomachs of experimental plaice that had fed contained between 126 and 890 Artemia nauplii in the $+F$ treatment. Two fish in the $-F$ treatment had 2 to 3 barnacle cyprids in the stomach. The presence of a Crangon predator did not affect the number of Artemia found in the stomachs of fish in the $+F$ treatment (Kruskal-Wallis non-parametric 1-way ANOVA: $H=$ $0.344, d f=1, p=0.558$ ). 


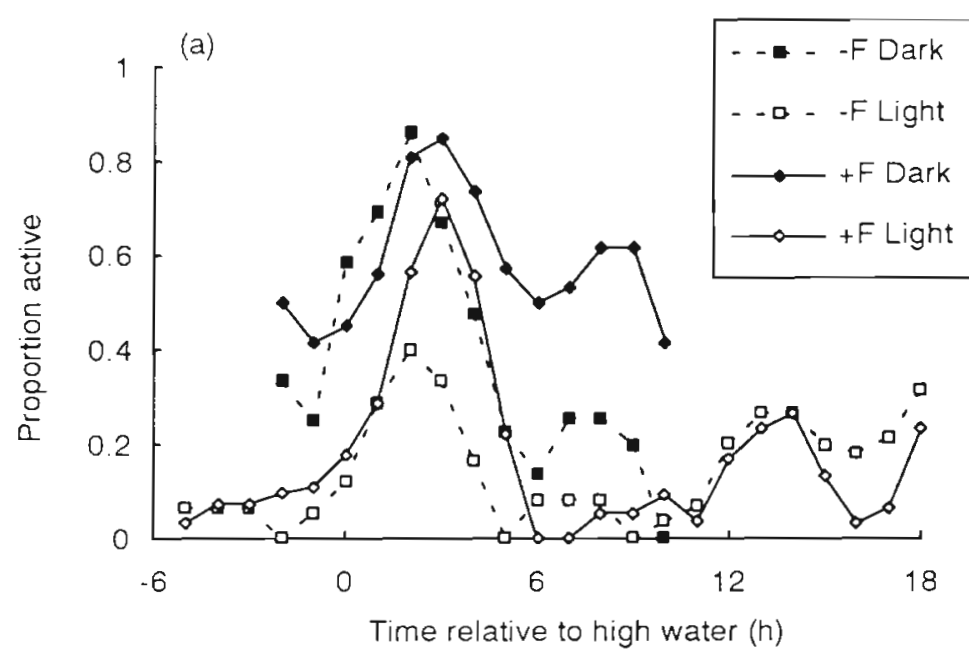

(b)

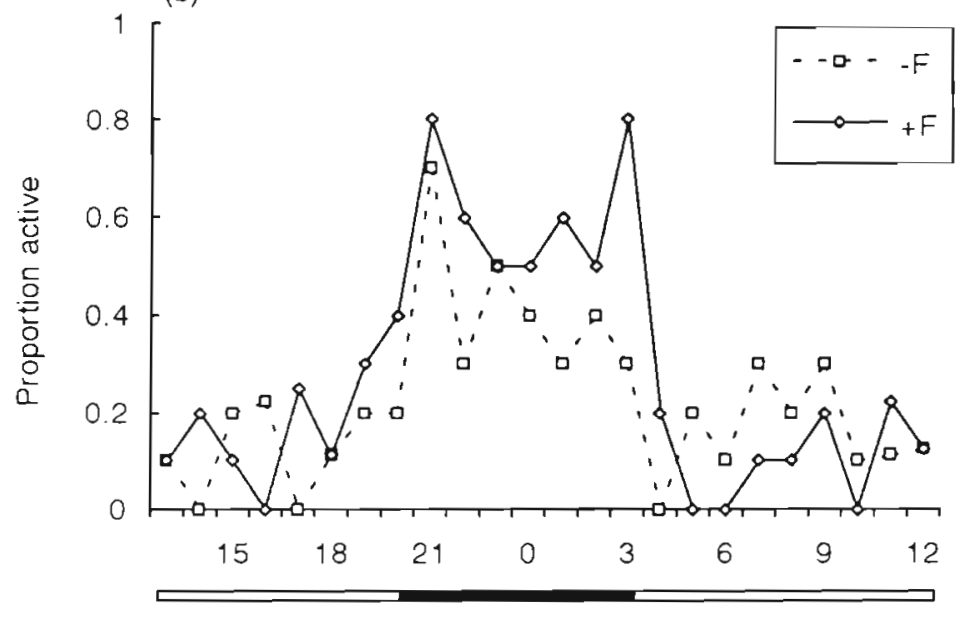

Time of day (h)

Fig. 3. Activity in the Crangon crangon predators (a) relative to the expected time of the first high water in the light and dark, and with and without food, (b) relative to the time of day. Each point is the proportion of the total number of trials in which the Crangon showed some movement in the $10 \mathrm{~min}$ observation period

\section{Variation in behaviour among individuals}

Considerable differences existed between individual fish in benthic and pelagic swimming and crawling on the tank walls. This variation was statistically significant (Table 1). Similar significant variation was also seen among the individual Crangon (Table 2). Correlations (35 in total: Table 3) were calculated between these individual measures of behaviour, including the number of Artemia in fish stomachs, and the experimental temperature, the sizes of fish and Crangon used, and the activity level of the Crangon (as the proportion of time spent active). The Bonferroni adjust- ment to the type I error probability $(\alpha)$ for $k=$ 35 tests requires probabilities of correlation coefficents to be less than $(\alpha / k=) 0.0014$ for significance at $\alpha=0.05$. Significant correlations were found between pelagic swimming activity and benthic swimming, and between pelagic swimming and movement on the sides of the tank, suggesting differences in overall activity among fish. Total benthic swimming was also significantly positively correlated with plaice size. Neither the number of Artemia in plaice stomachs nor shrimp size or activity was correlated with other variables. Feeding rate and Crangon activity were, however, positively correlated together.

\section{DISCUSSION}

The behaviour of small (15 to $30 \mathrm{~mm}$ ) 0 group plaice is strongly affected by light conditions and rhythmically synchronised with the tidal cycle. Swimming just above the surface of the sediment (benthic swimming) is largely restricted to the light period and is most frequent 0 to $2 \mathrm{~h}$ after the time of predicted high water. Swimming in the water column (pelagic swimming) is much more more frequent in darkness and reaches a maximum frequency 2 to $4 \mathrm{~h}$ after predicted high water in both light and darkness. Excess Artemia nauplii as prey reduces the amount of benthic swimming in the light, while the presence of a Crangon predator has apparently no effect on behaviour. Pelagic swimming is not affected by the presence of either food or a predator.

The activity pattern of the Crangon predators was similar to that observed by Al-Adhub \& Naylor (1975), with greater activity around the time of high water and in the dark. The lack of effect of Crangon on the behaviour of these fishes is in contrast with the strong inhibitory effect of juvenile cod Gadus morhua on benthic swimming and feeding success of larger juvenile plaice ( 45 to $90 \mathrm{~mm}$ total length: Burrows et al. 1994b). Unlike cod, the shrimps were inactive for much of the time during these experiments, and when they were active the plaice were generally inactive. This resulted in a greatly reduced encounter rate for the plaice with their predators (5 encounters in $160 \mathrm{~h}$ observation; cf. 133 encounters with cod in the same period). The lack of direct effect of the presence of a predator may reflect this low encounter rate. The reduced activity of the plaice in darkness may alternatively be a stereotypical 
Table 3. Kendall's rank correlations among variables measured for each trial. Symbols and abbreviations include: $\tau$, Kendall's rank correlation coefficient; p. probability of correlation; n, number of trials; TL, plaice Pleuronectes platessa total length; SL, plaice standard length; CL, Crangon crangon carapace length; CTL, C. crangon total length

\begin{tabular}{|c|c|c|c|c|c|c|c|c|c|c|}
\hline & & \multirow[t]{2}{*}{ Temp. $\left({ }^{\circ} \mathrm{C}\right)$} & \multicolumn{2}{|c|}{ Plaice size } & \multicolumn{2}{|c|}{ Crangon size } & \multirow{2}{*}{$\begin{array}{c}\text { No. of } \\
\text { Artemia }\end{array}$} & \multirow[t]{2}{*}{ Rise } & \multirow[t]{2}{*}{ Swim } & \multirow[t]{2}{*}{ Crawl } \\
\hline & & & $\mathrm{TL}$ & SL & $C L$ & CTL & & & & \\
\hline \multirow{3}{*}{$\begin{array}{l}\text { No. of } \\
\text { Artemia }\end{array}$} & $\tau$ & -0.0596 & 0.1603 & 0.1223 & -0.2713 & -0.3508 & \multirow[t]{3}{*}{-} & \multirow[t]{3}{*}{-} & \multirow[t]{3}{*}{-} & \multirow[t]{3}{*}{-} \\
\hline & $\mathrm{p}$ & 0.6741 & 0.2590 & 0.3895 & 0.2623 & 0.1334 & & & & \\
\hline & n & 31 & 31 & 31 & 13 & 13 & & & & \\
\hline \multirow{3}{*}{$\begin{array}{l}\text { Rise (mean } \\
\text { frequency) }\end{array}$} & $\tau$ & 0.1031 & 0.2676 & 0.3094 & 0.0406 & -0.0222 & -0.0448 & \multirow[t]{3}{*}{ - } & \multirow[t]{3}{*}{ - } & \multirow[t]{3}{*}{-} \\
\hline & $\mathrm{p}$ & 0.3813 & 0.0302 & 0.0126 & 0.8362 & 0.9051 & 0.7554 & & & \\
\hline & $\mathrm{n}$ & 40 & 37 & 37 & 18 & 18 & 31 & & & \\
\hline \multirow[t]{3}{*}{ Swim } & $\tau$ & 0.1058 & 0.4051 & 0.4422 & 0.2154 & 0.0350 & -0.1380 & 0.3791 & \multirow[t]{3}{*}{-} & \multirow[t]{3}{*}{ - } \\
\hline & $\mathrm{p}$ & 0.3536 & 0.0007 & 0.0002 & 0.2590 & 0.8466 & 0.3216 & 0.0010 & & \\
\hline & $\mathrm{n}$ & 40 & 37 & 37 & 18 & 18 & 31 & 40 & & \\
\hline \multirow[t]{3}{*}{ Crawl } & $\tau$ & 0.0301 & 0.1521 & 0.1945 & 0.0359 & -0.0653 & 0.0674 & 0.6433 & 0.2456 & \multirow[t]{3}{*}{ - } \\
\hline & $\mathrm{p}$ & 0.8069 & 0.2374 & 0.1325 & 0.8599 & 0.7344 & 0.6555 & 0.0001 & 0.0415 & \\
\hline & $\mathrm{n}$ & 40 & 37 & 37 & 18 & 18 & 31 & 40 & 40 & \\
\hline \multirow{3}{*}{$\begin{array}{l}\text { Crangon } \\
\text { activity }\end{array}$} & $\tau$ & 0.1170 & -0.1847 & -0.1557 & -0.0544 & 0.0000 & 0.6621 & -0.0515 & -0.1425 & 0.0309 \\
\hline & $p$ & 0.4896 & 0.3168 & 0.4028 & 0.7774 & 1.0000 & 0.0038 & 0.7635 & 0.3939 & 0.8610 \\
\hline & $\mathrm{n}$ & 20 & 17 & 17 & 18 & 18 & 13 & 20 & 20 & 20 \\
\hline
\end{tabular}

response to the expected increased activity of Crangon and other potential predators at night. It is surprising that the plaice showed no response to the Crangon given the vulnerability of plaice of this size (38 out of 40 were $<30 \mathrm{~mm}$ in length) to this predator in natural conditions (van der Veer \& Bergman 1987).

The effects of excess Artemia nauplii as food are opposite to those of the bivalve Donax vittatus (Burrows et al. 1994b). The presence of Donax buried in the sediment increases swimming on the bottom by stimulating searching behaviour. Artemia nauplii were very abundant in this study and may have produced satiation, reducing activity in well-fed fish. A similar effect has been observed in sole (Macquart-Moulin et al. 1991) which is thought to be a mechanism to retain fishes in areas of abundant food.

Comparatively few direct observations have been made of the behaviour of juvenile plaice in darkness. Evidence from field sampling of plaice populations (Gibson unpubl. obs.) suggests that intertidal migration continues in the dark hours, although in the Wadden Sea, plaice may venture less far from low water drainage gullies (Berghahn 1986). In a recent study using underwater television to observe movements of fishes near the bottom into the intertidal zone (Burrows et al. 1994a), many juvenile plaice were seen swimming in the light but none were seen in the hours of darkness. From this study it would seem that pelagic swimming produces movements of juvenile plaice in shallow water in darkness while movements in day- light comprise largely benthic swimming. This would explain the discrepancy between underwater television observations of movements on the bottom, which showed no nocturnal activity, and sampling by trawling (Gibson 1973a, unpubl. obs.) which showed continued movement at night.

A change from swimming on or near the bottom by day to swimming in midwater or at the surface at night has been seen in both larval plaice (Blaxter 1973) and adult plaice in both laboratory (Harder \& Hempel 1954, Bregnballe 1961, Verheijen \& de Groot 1967, Gibson et al. 1978) and natural conditions (Greer Walker et al. 1978). Similar diurnal changes have also been seen in flounder (Verheijen \& de Groot 1967) and sole (Kruuk 1963, de Veen 1967, Champalbert \& Castelbon 1989).

Pelagic and benthic swimming may have different functions. Pelagic swimming will reduce the number of encounters with benthic prey and with potential predators searching for food on the bottom (shrimps Crangon crangon, van der Veer \& Bergman 1987; shore crabs Carcinus maenas, A. D. Ansell unpubl. obs.; cod Gadus morhua, Edwards \& Steele 1968, Brawn 1969), but may increase vulnerability to visual fish and bird predators in the daytime. Benthic swimming brings the fishes into contact with both their prey and their epibenthic predators. Both modes of swimming could be used for migration: benthic movements are oriented in the necessary directions during daytime tidal and diurnal migrations (Gibson 1973a, Burrows et al. 1994a), while pelagic swimming in adults is 
strongly directional during the spawning migration (Metcalfe et al. 1993). Plaice larvae do use vertical movements in tidal currents to migrate into inshore areas (Creutzberg et al. 1978). Only benthic swimming could be used for feeding, since plaice feed exclusively on benthic organisms (e.g. Edwards \& Steele 1968, Poxton et al. 1983, Ansell \& Gibson 1990).

The different rates of encounter of juvenile plaice with their prey and predators during the 2 modes of swimming can be used as the basis for prediction, using optimal foraging theory (Burrows 1994), of the best mode to use in different conditions (Burrows in press). If feeding is visually mediated, benthic swimming should only be used in sufficient light to allow prey capture. In darkness and in areas of high risk of predation, juvenile plaice should use pelagic swimming to avoid contacts with their predators.

Acknowledgements. I am very grateful to Karen Hall for her analysis of the videotapes and to John Joyce, Lois Nickell and Linda Robb for all their help. I also thank Robin Gibson, Alan Ansell and Tim Ellis for useful discussions.

\section{LITERATURE CITED}

Al-Adhub, A. H. Y., Naylor, E. (1975). Emergence rhythms and tidal migrations of the brown shrimp Crangon crangon (L.). J. mar. biol. Ass. U.K. 55: 801-810

Ansell, A. D., Gibson, R. N. (1990). Patterns of feeding and movement of juvenile flatfishes on an open sandy beach. In: Barnes, M., Gibson, R. N. (eds.) Trophic relationships in the marine environment. Proc. 24th Eur. Mar. Biol. Symp. A.berdeen University Press, Aberdeen, p. 191-207

Ansell, A. D., Gibson, R. N. (1993). The effect of sand and light on predation of juvenile plaice (Pleuronectes platessa) by fishes and crustaceans. J. Fish Biol. 43: 837-845

Berghahn, R. (1983). Untersuchungen an Plattfischen und Nordseegarnelen (Crangon crangon) im Eulittoral des Wattenmeeres nach dem Übergang zum Bodenleben. Helgoländer Meeresunters. 36: 163-181

Berghahn, R. (1986). Determining abundance, distribution, and mortality of 0-group plaice (Pleuronectes platessa) in the Wadden Sea. J. appl. Ichthyol. 2: 11-22

Berghahn, R. (1987). Effects of tidal migration on the growth of 0-group plaice (Pleuronectes platessa L.) in the north Frisian Wadden Sea. Meeresforsch. 31: 209-226

Blaxter, J. H. S. (1968). Light intensity, vision and feeding in young plaice. J. exp. mar. Biol. Ecol. 2: 293-307

Blaxter, J. H. S. (1969). Visual thresholds and spectral sensitivity of flatfish larvae. J. exp. Biol. 51: 221-230

Blaxter, J. H. S. (1973). Monitoring the vertical movements and light responses of herring and plaice larvae. J. mar. biol. Ass. U.K. 53: 635-647

Brawn, V. M. (1969). Feeding behaviour of cod (Gadus morhua). J. Fish. Res. Bd Can. 26: 583-596

Bregnballe, F. (1961). Plalce and flounders as consumers of microscopıc bottom fauna. Meddr Kommn Danm. Fisk. -og Havunders. (N.S.) 3: 133-182

Burrows, M. T. (1994). An optimal foraging and migration model for juvenile plaice. Evol. Ecol. 8: 125-149

Burrows, M. T (in press). Predicting migration with optimal foraging theory: movements of juvenile plaice in shallow water. J. mar. biol. Ass. U.K

Burrows, M. T., Gibson, R. N., Maclean, A. (1994b). Effects of endogenous rhythms and light conditions on foraging and predator-avoidance in juvenile plaice. J. Fish. Biol. 45 (Suppl A): in press

Burrows, M. T., Gibson, R. N., Robb, L., Comely, C. A. (1994a). Temporal patterns of movement in juvenile flatfishes and their predators: underwater television observations J. exp. mar. Biol. Ecol. 177: 251-268

Champalbert, G., Castelbon, C. (1989). Swimming activity rhythms in Solea vulgaris (Q.) juveniles. Mar. Behav. Physiol 14: 201-209

Clark, C. W., Levy, D. A. (1988). Diel vertical migrations by juvenile sockeye salmon and the antipredation window. Am. Nat. 131: 271-90

Creutzberg, F., Eltinck, A. Th. G. W., van Noort, G. J. (1978) The migration of plaice larvae into the western Wadden Sea. In: McLusky, D. S., Berry, A. J. (eds.) Physiology and behaviour of marine organisms. Proc. 12th Eur. Mar. Biol Symp. Pergamon Press, Oxford, p. 243-252

de Veen, J. F. (1967). On the phenomenon of soles (Solea solea L.) swimming at the surface. J. Cons. perm. int. Explor. Mer 31: 207-236

Edwards, R., Steele, J. H. (1968). The ecology of 0-group plaice and common dabs at Loch Ewe. I. Population and food. J. exp. mar. Biol. Ecol. 2: 15-38

Forward, R. B. (1988). Diel vertical migration: zooplankton photobiology and behaviour. Oceanogr. mar. Biol. A. Rev. 26: $361-393$

Frost, B. W., Bollens, S. M. (1992). Variability of diel vertical migration in the marine planktonic copepod Pseudocalanus newmani in relation to its predators. Can. J. Fish. Aquat. Sci. 49: 1137-1141

Gibson, R. N. (1973a). The intertidal movements and distribution of young fish on a sandy beach with special reference to the plaice (Pleuronectes platessa L.). J. exp. mar Biol. Ecol. 12: 79-102

Gibson, R. N. (1973b). Tidal and circadian activity rhythms in juvenile plaice, Pleuronectes platessa. Mar. Biol. 22: $379-86$

Gibson, R. N. (1975). A comparison of field and laboratory activity patterns of juvenile plaice. In: Barnes, $\mathrm{H}$. (ed.) Proc. 9th Eur. mar. biol. Symp. Aberdeen University Press, Aberdeen, p. 13-28

Gibson, R. N. (1980). A quantitative description of the behaviour of wild juvenile plaice (Pleuronectes platessa L.). Anim. Behav. 28: 1202-1216

Gibson, R. N. Blaxter, J. H. S., de Groot, S. J. (1978). Developmental changes in the activity rhythms of the plaice (Pleuronectes platessa L.). In: Thorpe, J. E. (ed.) Rhythmic activity of fishes. Academic Press, London, p. 169-186

Greer Walker, M., Harden Jones, F. R., Arnold, G. P. (1978) The movement of plaice (Pleuronectes platessa) tracked in the open sea. J. Cons. perm. int. Explor. Mer 38: 58-86

Harder, W. Hempel, G. (1954). Studien zur Tagesperiodik der Aktivität von Fischen. I. Versuche an Plattfischen. Kurze Mitt. Inst. FischBiol. Univ. Hamburg 5: 22-31

Hill, A. E. (1991). A mechanism for horizontal zooplankton transport by vertical migration in tidal currents. Mar. Biol. 111: 485-492

Kruuk, H. (1963). Diurnal periodicity in the activity of the common sole, Solea vulgaris Quensel. Neth. J. Sea Res. 2 1-28

Kuupers, B. (1973). On the tidal migration of young plaice (Pleuronectes platessa) in the Wadden Sea. Neth. J. Sea Res. 6: 376-388 
Lockwood, S. J. (1980). The daily food intake of 0-group plaice (Pleuronectes platessa L.) under natural conditions. J. Cons. perm. int. Explor. Mer 39: 154-159

Macquart-Moulin, C., Champalbert, G., Howell, B. R., Patriti, G., Renaivoson, C. (1991). La relation alimentation-fixation benthique chez les jeunes soles Solea solea L. métamorphosées. Evidences expérimentales. J. exp. mar. Biol. Ecol. 153: 195-205

Metcalfe, J. D., Fulcher, M., Storeton-West, T J. (1991). Progress and developments in telemetry for monitoring the migratory behaviour of plaice in the North Sea. In: Priede, I. G., Swift, D. J. (eds.) Wildlife telemetry. Ellis Horwood, Chichester, p. 359-366

Metcalfe, J. D., Holford, B. H., Arnold, G. P. (1993). Orientation of plaice (Pleuronectes platessa) in the open sea: evidence for the use of external directional cues. Mar. Biol. 117: $559-566$

Poxton, M. G., Eleftheriou, A., McIntyre, A. D. (1983). The food and growth of 0-group flatfish on nursery grounds in the Clyde Sea area. Estuar. coast. Shelf Sci. 17: 319-337

Riley, J. D. (1966). Marine fish culture in Britain VII. Plaice (Pleuronectes platessa L.) post-larval feeding on Artemia salina L. nauplii and the effects of varying feeding levels. J. Cons. perm. int. Explor. Mer 30: 204-221

Rountree, R. A., Able, K. W. (1992). Foraging habits, growth

This article was presented by R. N. Hughes (Senior Editorial Advisor), Bangor, UK and temporal patterns of saltmarsh creek habitat use by young-of-year summer flounder in New Jersey. Trans. Am. Fish. Soc. 121: 765-776

Thijssen, R., Lever, A. J., Lever, J. (1974). Food composition and feeding periodicıty of 0 -group plaice (Pleuronectes platessa) in the tidal area of a sandy beach. Neth. J. Sea Res. 8: 369-377

van der Veer, H. W., Bergman, M. J. N. (1986). Development of tidally related behaviour of a newly settled 0-group plaice (Pleuronectes platessa) population in the western Wadden Sea. Mar. Ecol. Prog. Ser. 31. 121-129

van der Veer, H. W., Bergman, M. J. N. (1987). Predation by crustaceans on a newly settled 0-group plaice Pleuronectes platessa population in the western Wadden Sea. Mar. Ecol. Prog. Ser. 35: 203-215

Verheijen, F. J., de Groot, S. J. (1967). Diurnal activity of plaice and flounder in aquaria. Neth. J. Sea Res. 3: 393-390

Wolff, W. J., Mandos, M. A., Sandee, A. J. J. (1981). Tidal migration of plaice and flounders as a feeding strategy. In: Jones, N. V., Wolff, W. J. (eds.) Feeding and survival strategies of estuarine organisms. Plenum Press, London, p. $159-171$

Wyatt, T. (1972). Some effects of food density on the growth and behaviour of plaice larvae. Mar. Biol. 14: 210-216

Manuscript first received: May 6, 1994

Revised version accepted: August 15, 1994 